\title{
Engineering Students' Perceptions on the Pedagogical Practice of Teachers
}

\author{
Herivelto Moreira ${ }^{1, *}$, Isabel R. Gravonski ${ }^{1} \&$ Antonio Fraile Aranda ${ }^{2}$ \\ ${ }^{1}$ Programa de Pós-Graduação em Tecnologia, Universidade Tecnológica Federal do Paraná \\ (Technological Federal University at Paraná), Paraná, Brazil \\ ${ }^{2}$ Facultad de Educación y Trabajo Social, Universidad de Valladolid, España (Valladolid \\ University ) Valladolid, Spain \\ *Corresponding author: Postgraduate Program in Technology at Technological Federal \\ University at Paraná. Av. Sete de Setembro, 3165 Curitiba, Paraná, Brazil. \\ Tel: 55-41-3310-4725 E-mail: herivelto.moreira51@gmail.com
}

Received: October 8, 2012 Accepted: March 27, 2013 Published: June 15, 2013

doi:10.5296/ije.v5i2.2509 URL: http://dx.doi.org/10.5296/ije.v5i2.2509

\begin{abstract}
This study surveyed Brazilian engineering $(n=252)$ students' perceptions of teaching and learning strategies most frequently used by teachers at a public institution in south Brazil. Responses were analyzed using descriptive statistics, coefficient Cronbach alpha reliability and Kruskal-Wallis ANOVA. These students identified that the most frequently used methodologies were teacher-centered. It also showed the importance of investigating students' perceptions to identify situations that can be used to modify teachers' action in the classroom. Implications for faculty development and the need to include teaching strategies that allow students to have a greater participation in the learning process are discussed.
\end{abstract}

Keywords: engineering education; pedagogical practice in higher education; teaching strategies; active learning 


\section{Introduction}

The importance of engineering to the growth of a country is unquestionable as well as the discussions about education in engineering. In this sense, there are some fundamental issues in the preparation of these professionals that are necessary to enhance and complement the teaching of engineering.

One of these issues is directly related to teaching and learning, because in a structured educational environment, learning takes place in multiple ways. However, all of them require of the higher education teacher knowledge of students' learning styles and mastery of teaching strategies to deal with the body of knowledge specific to each subject matter.

Today it is common to hear about student-centered learning, i.e., the use of teaching strategies that promote students' action, autonomy and responsibility (active, collaborative, cooperative learning, etc.). This trend, which has been taking place at other educational levels for quite some time, is now also common in higher education, thanks to several changes in Brazilian Higher Education such as the expansion of enrollment in higher education courses, the flexibility of the system, changes in curriculum structure, changes in admission criteria, requirement of faculty qualification and systematic processes of internal and external institution evaluation.

To deal with these changes, one of the challenges that higher education teachers face lies in the use of teaching and learning strategies and techniques that promote students' development of professional competences.

Another challenge is added to this one: the challenge of using teaching and learning strategies in line with these changes, that is, strategies that promote a deeper learning in students as opposed to learning that is more superficial by nature (characterized by transmission and reproduction of information). Research and new practices in education advocate that teaching and learning processes that rely only on the logic of the transmission and reproduction are not the most appropriate to answer these requests.

In this context, the advantages of active learning, in response to the promotion of competence requirements, have been pointed out. This approach is generally defined as any teaching method that engages students in the teaching and learning process.

Active learning requires that students participate in meaningful activities and think about what they are doing in order to promote their own involvement in the process of knowledge construction and to foster the development of cognitive, relational and personal competences.

The adoption of this approach necessarily implies a change in the traditional role of the teacher that is replaced by one that includes the facilitation and coordination of groups of students, who take responsibility for their learning process.

The present study addresses from students' perspective, the different teaching strategies used by engineering teachers. Students often have little expertise in knowing if the method selected by an individual teacher was the best teaching method or just "a method" or simply the method with which the teacher fells most comfortable.

In order to address this issue, first, this paper defines what active learning is and distinguishes the different types of strategies most frequently discussed in the national and international 
educational literature, particularly in the field of engineering. Second, it provides an overview of relevant issues for the reader to try to draw conclusions about the use of active learning.

\section{Literature Review}

Throughout the last decades, the higher education system in Brazil has experienced several changes such as the increase in the number of vacancies in the public universities, the flexibility of the academic system, changes in curriculum structure (National Curriculum Guidelines), changes in admission criteria, requirement of faculty qualification, systematic processes of internal and external evaluation, both at institutional and national levels, among other indicators (Cunha, 2010; Pachane and Pereira, 2004).

In addition to these changes, we find in the research literature reflections on the challenge of bringing learners to participate more effectively in classroom discussions. In many cases, it is clear that the difficulty for teachers is not in scientific knowledge, but in the appropriate way to work such knowledge in order to promote student learning (Kolari and Savander-Ranne, 2002; Masetto, 2001; Moreira, Pryjma and Buiar, 2010).

This difficulty is based on the argument used by several authors in the field of education (De Miranda, 2008; Duch, Groh and Allen, 200; Kolari and Savander-Ranne, 2002; Ribeiro, 2005) that we still find in higher education, the persistent influence of traditional trends permeating the action of teachers. Despite so many decades have passed these trends remain strong, guiding the practice of most teachers.

According to Cunha (2005, p.9-10), the aforementioned trends are based on the following assumptions: a) knowledge is regarded as finished and without roots, that is, historically decontextualized, b) the intellectual discipline is taken as a reproduction of words, texts and experiences of the teacher, c) memorization is valued for accuracy and security, d) each discipline in the curriculum is designed as the domain of knowledge and there is a fight to have a higher number of classes in order to cover all the content, e) the teacher is the main source of information and he/she feels uncomfortable when he/she has no ready answers for all students, and f) research is seen as an activity for experts, beyond the reach of undergraduate students, where the methodological apparatus and the instruments of certainty overlap the intellectual capacity to work with doubt.

This traditional approach is usually located in curricula based on the model of technical rationality. For Schön (1990) this model assumes professional practice as a mere branch of available techniques to achieve ends, chosen within manageable boundaries and therefore it only values learning of this kind of knowledge.

Lecture is one of the most frequently used instructional methods in higher education. It assumes the teacher to be the expert and is an efficient way of disseminating information. Most teachers agree that the purpose of lectures is to lay foundations as the student works through the subject, and good lecturers know their students and develop their lectures according to students' needs. 
Although the lecture method is still considered effective, Duch, Groh and Allen (2001, p.5) attribute its persistence in higher education, mainly because it is familiar, easy and recalls how teachers learned (apprenticeship of observation). However, it does not really favors the development of procedural skills to complement scientific knowledge.

In relation to engineering courses, several researchers (Asokanthan, 1997; Krivickas, 2005) state that also in these courses are still prevalent traditional teaching methods and approaches. These approaches emphasize the teacher as expert, as a key element in the transmission of content.

Related to the Brazilian reality, Buonicontro (2002, p.1) states that it is common, in meetings in which engineering education is discussed, to speak of pedagogical renewal as an emerging need to face the challenges of today's changing society, but this discussion is usually unrelated to teachers (engineers) who teach on those courses.

Another relevant aspect in this discussion is the argument of Fazio and Millioni $(2009$, p.1) that "the simple observation of the curricular structure of engineering schools in Brazil is enough to notice that they do not really dare and remain faithful to an orthodox style of training (in other words traditional) which may have worked for some time, but now it does not respond to the demands of the knowledge society".

Menges and Austin (2001) corroborate this statement based on a meta-analysis, whose results showed a large diffusion of this teaching method originated in exact and applied sciences, in which a prevailing institutional culture is guided by a positivist approach of science, and by institutions that house graduate programs and, consequently, research - a description which in Ribeiro's opinion (2005) is very close to the Brazilian engineering schools, particularly the public ones.

The limitation of the traditional proposal, combined with the growing innovations, stimulated the scientific community to search for alternatives of new processes of teaching and learning which are able to prepare future engineers in a holistic view, integrating science with practice, through active learning and based on competences. A new model of learning to learn, in the education field, gained momentum with the advent of the computer and later the Internet, strengthening the teaching and learning process, favoring all equitably and giving access to information. Similarly, new styles of teaching and learning are studied in the context of engineering education and their effects on the quality of learning (Felder and Silverman, 1988).

The changes in the way of conceiving teaching and learning process certainly present challenges to teachers because they require the inclusion of methodologies aimed at developing in higher education students the competences that the world of work demands, i.e., critical thinking, the capacity of learning to learn, self-confidence, communication skills and teamwork, sense of responsibility and initiative, ability to make decisions, to solve problems and conflicts (Gonçalves \& Silva, 2008).

We can also add to this situation, the challenge of using teaching and learning strategies more appropriate to these objectives, strategies that promote deeper learning (e.g. making 
connections, looking for patterns and establishing logic) as opposed to learning that is more superficial by nature (characterized by transmission of information and its reproduction). The use of teaching methods that encourage deep learning would lead students to ask themselves: Why did this happen? How can this happen again? What do I need to know in order to make sense of this content? Where does this idea fit into what I already know? How do I challenge this idea? To try to answer the above questions, it is necessary to reflect on the social and economic context in which the engineer is being formed.

In this respect, Longo (2004, as cited in Reis, 2008, p.3) suggests a methodological and content review in engineering courses, aiming at the contribution of these professionals to search for greater scientific and technological autonomy of the country.

These questions lead us to reflect on how the engineering courses may take more current methodological perspectives to meet the needs expressed in the literature and official Brazilian documents, because a pressing problem is how to engage students actively and reflexively in the learning process.

Analysis of the international research literature (Chickering and Gamson 1987; Göl and Nafalski, 2007; Bonwell and Eison, 2000), however, suggests that students should do more than just listen. They should: read, write, discuss, or be engaged in problem solving.

More importantly, to actively participate, students must be engaged in operations of higher-order thinking such as analysis, synthesis and evaluation. In this context, it is proposed that the strategies that promote active learning be defined as educational activities that involve students in doing and thinking about what they are doing.

Active learning has received considerable attention over the last years and has attracted strong supporters in all areas of education. These supporters are teachers who seek alternatives to traditional teaching and learning methods. It is often presented or perceived as a radical change in the way of teaching and, of course, that polarizes the attention of teachers and students.

Although there is no consensus on the terms related to this type of learning (active, collaborative, cooperative), it is possible to provide some general accepted definitions and highlight the distinctions of understanding about common terms.

According to Bonwell and Eison, active learning is generally defined as any teaching method that engages students in the learning process. For the authors, "active learning requires students to participate in meaningful activities and to think about what they are doing" (2000, p.2). Although this definition might include traditional activities such as homework, in practice active learning refers to activities that are introduced in the classroom.

Some authors (Feld, Brent and Stice, 2002; Millis and Cottell Jr., 1998) argue that collaborative learning refers to any teaching method in which students work together in small groups to achieve a common goal.

As such, collaborative learning encompasses all methods based on groups, including cooperative learning. In contrast, some authors distinguish between them and argue that they 
have different historical developments and different philosophical roots (Bruffee, 1995). For Göl and Nafalski (2007), collaborative learning "favors deep learning within a small team environment, where the individual team members unselfishly strive to contribute their utmost towards achieving the best learning outcomes for the team". (p.174). Notwithstanding, in any interpretation, the central element of collaborative learning is the emphasis on student interaction, instead of learning as a solitary activity.

Cooperative learning is defined as a structured form of group work, in which students seek common goals, although they are evaluated individually. (Feden and Vogel, 2003, Millis and Cottell Jr., 1998). The most common model of cooperative learning found in the engineering literature is that of Johnson, Johnson and Smith (1998). This model incorporates five specific principles that are: individual responsibility, mutual interdependence, face to face interaction, practice of appropriate interpersonal skills and regular self-assessment of teamwork. Although there are different models of cooperative learning (Slavin, 1983; Stahl, 1994) the central element is the focus on incentives for cooperation rather than competition to promote learning.

Active learning is also known as cooperative learning, in which students work problems or projects in small groups to improve the understanding of the content in a specific discipline. Each group member is responsible not only for his/her learning, but also to help colleagues to learn.

Active learning is, in short, any activity that students do in the classroom beyond passively listening to the teacher's lecture. This varies from practices which help students absorb what they hear, to short writing exercises in which students react to the material exposed, to techniques with complex exercises in which students apply course material to new problems in real life situations.

The use of the term active learning by educators is based more on intuitive understanding than on a common definition. Consequently, many teachers state that all learning is inherently active and that students are therefore actively involved while listening to formal presentations in the classroom.

The use of these methods in the classroom is vital because of the impact on student learning. For example, several studies in the area of engineering education (Asokanthan 1997, Göl and Nafalski, 2007; Krivickas, 2005) have showed that students prefer strategies promoting active learning to traditional lectures, because these strategies are superior to lectures since they promote the development of students' skills in thinking and writing.

Therefore, such an approach requires teachers to know the transition between traditional teaching and learning methods and active methodologies. It is worth remembering that the different teaching and learning techniques should be used to supplement, not replace the lectures, since we should not advocate a complete discarding of the lecture, since this strategy is also effective mainly when used in combination with other methods.

In addition, restructuring the engineering curricula becomes a fundamental aspect for students to take leading roles in several areas, develop the ability to learn throughout life, contribute to 
the profession and be successful in a market of multidisciplinary work.

The essential elements of active learning are student activities and the involvement in the learning process. Active learning contrasts with the traditional classes, where the students passively receive information from the teacher.

The literature in the area and the official documents in Brazil suggest that the undergraduate courses in engineering should use active methodologies to monitor and evaluate teaching and learning process and the course itself, in line with the evaluation system and the curriculum dynamics defined by the institution to which they belong. However, some questions still persist in the context of higher education, especially as to how they can be applied in engineering education, since teachers from the area also consider teaching through work and laboratories as active.

In this sense, it is important to know the nature of the active learning, to empirically investigate how students perceive its use by teachers, and because numerous studies indicate that students are the most qualified sources to report on the extent to which the learning experience was productive, informative, satisfying, or worthwhile. While opinions on these matters are not direct measures of teacher or course effectiveness, they are legitimate indicators of student satisfaction, and there is substantial research linking student satisfaction to effective teaching (Theall and Franklin, 1990).

This review shows the urgency of the problem, because little research is done on how students perceive the teaching and learning methodologies used by teachers, that is, what methods they think are important for learning and training, and if their views reflect the teachers' views?

Thus, the aim of the study was to identify engineering students' perceptions about teaching and learning strategies used by engineering teachers at a public university in south Brazil.

\section{Methodology}

This study adopted a survey approach and the instrument used to collect data was a questionnaire. The instrument was an adapted version of that utilized in Fraile Aranda (2009). This instrument had originally been designed for use with undergraduate physical education students in Spanish Universities, and therefore needed to be modified for use with Brazilian engineering students (e.g. the scales used in the instrument were adjusted to refer to the Brazilian context). Changes were also made to the wording of some of the items of the scale. The instrument was translated into Portuguese by the first and second researchers then back translated by a second native speaker of Portuguese and was finally checked against the original Spanish version by the first and second researchers. The questionnaire was then piloted with forty engineering students from the same population. Further revisions and modifications were made to some of the questions after the piloting.

The final version of the questionnaire contained four sections. The first section collected demographic data. The next section contained nineteen items designed to understand general 
aspects related to the methods, techniques, and strategies used by teachers in classroom (ASMA). The next section contained twenty one items designed to understand general aspects related to the strategies and techniques of both evaluation and grading used by teachers (ASEP). Finally the last section contained nineteen items designed to delimitate the most important competences of the engineer developed in the different subjects throughout their academic training (ASCO). For this article, only the results of the Assessment Scale of the Methodological Aspects (ASMA) will be reported. Participants responded to these scales items using a five points likert-type scale with anchors at 1 (never), 2 (rarely), 3 (sometimes), 4 (frequently) and 5 (always). The questionnaire was circulated in hard copy to all students from the 4th and 5th years in the institution involved here. Participation was voluntary. The participants were invited to sign an informed consent form, and were also provided with an outline of the study at the start of the questionnaire. Data analysis was supported by the software package Statistica 7, and took the form of descriptive statistics, comparisons of means, and coefficient Cronbach alpha reliability. Given the nature of the data (e.g. predominantly ordinal in nature), non-parametric statistical tests were used (e.g. Mann-Whitney U Test for 2 independent samples and Kruskal-Wallis ANOVA for multiple comparisons between courses).

\section{Results}

Questionnaires were returned by 252 respondents (206 males, 46 females), giving a response rate of $40 \%$. We consider this a reasonable level of response given the length of the questionnaire, and considering the lack of culture in the institution to value the opinion of students regarding to the evaluation of teaching and the course. The average age of the students is 23 years old. Of the total respondents, $82 \%$ are male and $18 \%$ are female. In relation to the courses, $29 \%$ are students from the Electronic Engineering course, 34\% are from the Electrical Engineering course, 14\% are from the Mechanical Engineering course and $23 \%$ are from the Civil Engineering course. In the distribution of the sample according to the academic placement, $60 \%$ are students of the 4 th year and $40 \%$ are of 5 th year.

Section 2 of the questionnaire asked respondents to indicate how often teachers used the strategies and teaching techniques listed on the ASMA scale. Table 1 summarizes their responses. These show that the strategies with the highest means were "resolution of exercises in class" and "lecture", while the strategies with the lowest mean were "round tables with experts" and "portfolio". No significant difference ( $p>0.050)$ between the sexes in the nineteen items of the scale (Table 1) 


\section{1) Macrothink}

International Journal of Education

ISSN 1948-5476

2013, Vol. 5, No. 2

Table 1: Mean, standard deviation, minimum and maximum, and rank for the 'Scale of assessment of methodologies' $(n=252)$

\begin{tabular}{llllll}
\hline Teaching strategies evaluated & Mean & SD & Min. & Max & Rank \\
\hline Resolution of exercises in class & 3,87 & 0,77 & 1 & 5 & 1 \\
Lecture & 3,63 & 1 & 1 & 5 & 2 \\
Problem-based learning & 3,56 & 0,88 & 1 & 5 & 3 \\
Lab practices & 3,14 & 0,82 & 1 & 5 & 4 \\
Lecture/discussion & 3,09 & 1 & 1 & 5 & 5 \\
Project-based learning & 3,03 & 0,81 & 1 & 5 & 6 \\
Seminars & 2,69 & 0,86 & 1 & 5 & 7 \\
Research-based teaching & 2,57 & 0,95 & 1 & 5 & 8 \\
Reading texts & 2,46 & 0,88 & 1 & 5 & 9 \\
Virtual platforms (Moodle and others) & 2,41 & 0,95 & 1 & 5 & 10 \\
Case studies & 2,4 & 0,82 & 1 & 5 & 11 \\
Programmed instruction & 2,33 & 0,99 & 1 & 5 & 12 \\
Group dynamics & 2,19 & 0,79 & 1 & 5 & 13 \\
Discussion lists by computerized means & 2,11 & 0,88 & 1 & 5 & 14 \\
Discussion and debates & 2,1 & 0,79 & 1 & 5 & 15 \\
Concept Map & 1,87 & 0,94 & 1 & 5 & 16 \\
Field study & 1,83 & 0,71 & 1 & 4 & 17 \\
Portfolio & 1,68 & 0,88 & 1 & 5 & 18 \\
Round table with one or more experts Panel of & & & & & \\
experts & 1,30 & 0,53 & 1 & 3 & 19 \\
Reliability coefficient & & 0,77 & & & \\
\hline
\end{tabular}

$0.74<$ item-total correlation $<0.78$,

Scale internal consistency (by Cronbach's alpha) $=0.77$, good according to Davis (1964) and Numnally (1978).

In the same scale the respondent were asked to indicate how teachers developed the content of their lessons in classroom. Table 2 summarizes respondents' opinions on the actions of teachers to articulate the teaching process in the classroom. The results reveal that the use of audio-visual resources is perceived by students as the most often practice used by teachers and the dynamics in the classroom environment are the least used strategies. 
Table 2: Mean, standard deviation, minimum and maximum, and rank for the 'Scale of the actions of teachers in the classroom' $(n=252)$

\begin{tabular}{|c|c|c|c|c|c|}
\hline Description of the development of the classes & Mean & SD & Min. & Max. & Rank \\
\hline $\begin{array}{l}\text { Audiovisual resources for the development of } \\
\text { classes }\end{array}$ & 3,58 & 0,8 & 1 & 5 & 1 \\
\hline Classes for the resolution of problems & 3,47 & 0,84 & 1 & 5 & 2 \\
\hline Classes to solve Problems & 3,19 & 0,86 & 1 & 5 & 3 \\
\hline $\begin{array}{l}\text { Classes which establish connection between the } \\
\text { discipline and the professional context }\end{array}$ & 2,98 & 0,84 & 1 & 5 & 4 \\
\hline $\begin{array}{l}\text { Teachers' permanence for the resolution of } \\
\text { questions }\end{array}$ & 2,94 & 1,03 & 1 & 5 & 5 \\
\hline $\begin{array}{l}\text { Classes where the teachers use various } \\
\text { methodological strategies }\end{array}$ & 2,55 & 0,77 & 1 & 5 & 6 \\
\hline Dynamics in the classroom environment & 2,38 & 0,98 & 1 & 5 & 7 \\
\hline Reliability coefficient & & 0,74 & & & \\
\hline
\end{tabular}

When trying to figure out differences between engineering courses in the items in Table 3, we found no significant differences for the items "Dynamics in the classroom environment" ( $p=$ $0.1002)$ and "Classes for the resolution of problems" $(p=0.1030)$ between the courses. For the other items it is possible to observe that there were significant differences between the Electronic Engineering course in relation to the Civil Engineering course and the Mechanical Engineering course. Data from the Electronic Engineering course have a lower mean on these items. For the item "classes where the teachers use various methodological strategies" there were a significant difference $(\mathrm{p}=0,0242)$ between the Mechanical Engineering course and Civil Engineering. Data from the Mechanical Engineering have a lower mean in this item.

Table 3: Results of the comparison (Kruskal-Wallis ANOVA and multiple comparisons) of the scores between the courses $(\mathrm{C} 1=$ Electrical Engineering, $\mathrm{C} 2=$ Electronics Engineering, $\mathrm{C} 3=$ Mechanical Engineering, $\mathrm{C} 4=$ Civil Engineering $)(\mathrm{n}=252)$

\begin{tabular}{ll}
\hline \multicolumn{1}{c}{ Item } & $\begin{array}{l}\text { Multiple } \\
\text { and } \mathrm{p} \text { value }\end{array}$ \\
\hline $\begin{array}{l}\text { Dynamics in the classroom environment } \\
\text { Classes for the resolution of problems }\end{array}$ & $\begin{array}{l}(\mathrm{p}=0,1002) \\
(\mathrm{p}=0,1030)\end{array}$ \\
Teachers' permanence for the resolution of questions & $\mathrm{C} 1 \neq \mathrm{C} 4(\mathrm{p}=0,0101)$ \\
& $\mathrm{C} 1 \neq \mathrm{C} 3(\mathrm{p}=0,0007)$ \\
Audiovisual resources for the development of classes & $\mathrm{C} 1 \neq \mathrm{C} 4(\mathrm{p}=0,0035)$ \\
Classes to solve problems & $\mathrm{C} 1 \neq \mathrm{C} 4(\mathrm{p}=0,0019)$ \\
Classes which establish connection between the discipline and the & $\mathrm{C} 1 \neq \mathrm{C} 4(\mathrm{p}=0,0011)$ \\
professional context & $\mathrm{C} 3 \neq \mathrm{C} 4(\mathrm{p}=0,0242)$ \\
Classes where the teachers use various methodological strategies
\end{tabular}




\section{Discussion of the Results}

The main objective of this study was to identify engineering students' perceptions about teaching and learning strategies used by teachers at a public university in south Brazil. It also sought to identify which were the most and least teaching strategies and resources used by teachers in the classroom.

In respondents' view, the teaching strategies most used by teachers are the "lectures", "resolution of exercises" and "lab practice". This corroborates the results of other studies (Menges and Austin, 2001; Ribeiro, 2005) regarding the use of traditional teaching strategies in the engineering courses.

The low frequency of respondents' indications for "reading texts" and other active methodologies can be credited to two aspects: a) that scientific knowledge is brought into the classroom exclusively by the teacher and b) to the teachers' unfamiliarity with active methodologies in the teaching and learning process. This second aspect was also presented in Ribeiro (2005, p.26) who argues that most of the faculty from the engineering courses do not have pre-service or in-service teacher training, and for this reason favor traditional teaching methods they themselves experienced as students, since they allow greater control over what happens in the classroom.

Regarding the development of the lessons and the use of resources, it is possible to observe that audio-visual resources have been used by teachers to deliver lectures. Such use of audio-visual resources apparently does not characterize a new teaching strategy, but often the replacement of blackboards, contrary to what different authors (Felder and Silverman, 1988; Masetto, 2001) discussed in the literature review.

Due to what has already been stated by several authors in the literature review, it is possible to infer that teachers in the engineering courses in the institution involved here are not prepared to work with active methodologies, that is, to use learning based on student and not based only on the teacher.

However, working with active methodologies should help students better understand what it means to be an engineer, not only through the teaching of a variety of engineering skills, but also through active approaches that will help them to cope with the demands and activities of their professional practice.

\section{Conclusions}

The results of this study suggest the need to include in the curricula planning of these four engineering courses approaches that allow students to have a greater participation in the learning process. This participation can help increase student motivation and contribute to reduce the dropout rate observed in these courses.

In other words, we can encourage students to stay in the engineering courses by offering a teaching more centered on the student than on the teacher. This requires that the teachers and 
the institution be committed to the pedagogical issues that are inherent to teaching.

The study results also point out to the need of using teaching and learning methodologies that involve students in activities directed towards the construction of meanings. This alone makes it clear the importance of working with active methodologies in engineering courses, especially because this is something that affects not only the permanence of the student but also the quality of training and the recognition of the institution in society. When inserting these methodologies, the teacher becomes a facilitator rather than being the central figure of the teaching and learning process.

It is also important to emphasize that when the teacher directs and stimulates the teaching process according to the intended learning he/she deliberately uses a set of actions, steps, external conditions and procedures that is called method. Therefore, there is no single method, but methods that are more appropriate to achieve certain goals.

We need to acknowledge that this study, while generating a range of insights, is based on responses provided by just over $40 \%$ of the 617 students who are enrolled in the four courses studied here. Overall, though, we feel that the questionnaire used generated data on a range of issues central to understanding students' perceptions about teaching and learning strategies used by teachers in classroom. The study we have reported here, too, can also be both replicated, as well as extended through more qualitative work, both in the specific context examined here as well as in a range of university settings internationally.

We believe that increasing the quality of the teaching and learning processes in the engineering courses in the institution on both pedagogical methods and technology contents; will result in engaged and motivated students.

\section{References}

Asokanthan, S. F. (1997). Active learning methods for teaching dynamics: development and $\begin{array}{llll}\text { implementation. } & \text { Retrieved } & \text { August } & \text { from }\end{array}$ http://fie-conference.org/fie97/papers/1387.pdf

Bonwell, C. C., \& Eison, J. A. (2000). Active Learning: Creating Excitement in the Classroom. Retrieved May 2010 from http://www.ydae.purdue.edu/lct/hbcu/documents/Active_Learning_Creating_Excitement in_the_Classroom.pdf

Bruffee, K. A. (1995). Sharing our toys: cooperative learning versus colaborative learning. Change, 12(18). http://dx.doi.org/10.1080/00091383.1995.9937722

Buonicontro, C. M. S. (2002). O processo de construção da prática pedagógica do engenheiro-professor. 25a Reunião Anual da ANPed, Caxambú, Minas Gerais. Retrieved March 2012 from http://www.anped.org.br/reunioes/25/texced25.htm\#gt11

Chickering, A. W., \& Gamson, Z. F. (1987). Seven Principles for Good Practice. AAHE Bulletin, 39, 3-7. 
Cunha, M. I. (2005). O professor universitário na transição de paradigmas. ( 2 nd ed.). São Paulo: Junqueira \& Martins Editores.

Cunha, M. I. (2010). La calidad de la educación superior en Brasil en el contexto de la democratización: desafíos y perspectivas. LASA2010 / Crisis, Response, and Recovery, XXIX International Congress of the Latin American Studies Association, October 6-9, 2010, Toronto, Canada. Retrieved from http://www.lasa.international.pitt.edu/members/congress-papers/lasa2010/files/2768.pdf

Davis, F. B. (1964). Educational measurements and their interpretation. Wadsworth Publishing Co.: Belmont, California.

De Miranda, M. A. (2008). Pedagogical Content Knowledge and Engineering and Technology Teacher Education: Issues for thought. Journal of the Japanese Society of Technology Education, 50(1), 17-26.

Duch, B. J., Groh, S. E., \& Allen, D. E. (2001). Why problem-based learning? A case study of institutional change in undergraduate education. In: B. J, Duch,. et al. (Eds). The power of problem-based learning. Sterling: Stylus, p.3-11.

Fazzio, A. e Millioni, A. (2009). Do ensino de engenharia no Brasil. Jornal da Ciência (SBPC). $\quad$ Retrieved $\quad$ May 2011 from http://www.jornaldaciencia.org.br/Detalhe.jsp?id=64359

Feden, Preston D., \& Vogel, Robert M. (2003). Methods of Teaching: Applying Cognitive Science to Promote Student Learning. McGraw Hill Higher Education.

Felder, R. M., \& Silverman, L. K. (1988). Learning and Teaching Styles in Engineering Education. Engineering Education, 78(7), 674-681 (1988). Retrieved September 2011 from: http://www4.ncsu.edu/unity/lockers/users/f/felder/public/Papers/LS-1988.pdf

Felder, R., Brent, R., \& Stice, James (2002). National Effective Teaching Institute: Workshop Materials. American Society for Engineering Education Annual Conference, Montreal, Quebec, Canada.

Fraile Aranda, A. (2009). El Espacio Europeo de Enseñanza Superior: un Controvertido Camino para la Formación y el Cambio Educativo del Profesorado Universitario. Revista Universidades, Universidade de México, n.40, p.3-17.

Göl, Ö., \& Nafalski, A. (2007). Collaborative learning in engineering education. Global Journal of Engineering Education, 11(2), Australia. Retrieved June 2011 from http://198.66.238.102/journals/GJEE/Publish/Vol.11,No.2/GolNafalski.pdf

Gonçalves, S. e Silva, S. (2008). Pedagogia no ensino superior. Escola Superior de Educação de Coimbra, June. ISSN: 1647-032X.

Johnson, D. W., Johnson R., T., \& Smith, Karl, A. (1998). Active Learning: Cooperation in the College Classroom (2nd Edition). Edina, MN: Interaction Book Company.

Kolari, S., \& Savander-Ranne, C. (2002). Does Pedagogical Training Benefit the Engineering 
Educator? Global Journal of Engineering Education, 6(1), 59-69.

Krivickas, R. V. (2005). Active learning at Kaunas University of Technology. Global Journal of Engineering Education Australia, 9(1), 43-47.

Masetto, M. T. (2001). A Renovação Pedagógica na Engenharia e a Formação dos Formadores de Engenheiros. Retrieved August 2011 from http//:www.engenheiro2001.org.br/artigos

Menges, R. J., \& Austin, A. E. (2001). Teaching in higher education. In: Richardson, V. (ed.) Handbook of research on teaching. AERA, p.1122-1156, Washington.

Millis,B. J., \& Cottell, P. Jr. (1998). Cooperative learning for higher education faculty, American Council on Education, Series on Higher Education. The Oryx Press, Phoenix, AZ.

Morais, M. de F. (2009). A utilização de métodos participativos no ensino de Engenharia de Produção: O caso do curso de engenharia de produção agroindustrial da FECILCAM. IV Encontro de Produção Científica e Tecnológica, 20 a 23 de outubro de 2009. Retrieved June 2011 from http://www.fecilcam.br/nupem/anais_iv_epct/PDF/engenharias/04_MORAIS.pdf

Moreira, H., Pryjma, M., \& Buiar, D. (2010). A formação continuada dos professores de engenharia da UTFPR: um relato de experiência. Anais do XXXIII Congresso Brasileiro de Educação em Engenharia, Fortaleza, September 12 - 15.

Nunnally, J. C. (1978). Psychometric theory. New York: McGraw-Hill Inc.

Pachane, G. G., \& Pereira, E. M. A. (2004). A importância da formação didático-pedagógica e a construção de um novo perfil para docentes universitários. Revista Iberoamericana de Educación. N.33/4. Retrieved August 2011 from http://www.rieoei.org/edu_sup26.htm

Pereira, C. F., Afonso, R. A., Santos, M. J., Araújo C. A. L., \& Nogueira M. (2007). Aprendizagem baseada em problemas (ABP)- uma proposta inovadora para os cursos de engenharia. XIV SIMPEP, 05 - 07 November 2007. Retrieved May 2010 from http://www.nogueira.eti.br/profmarcio/obras/publicado_1474.pdf

Reis, C. A. C. (2008). A formação do professor de engenharia. Retrieved August 2011 from http//:www.senept.cefetmg.br/galerias/Arquivossenept/anais/tercaTema3/TerxaTema3Ar tigo11.pdf

Ribeiro, L. R. C. (2005). A aprendizagem baseada em problemas (PBL): uma implementação na educação em engenharia na voz dos autores. 209p. Doctoral Thesis . Programa de Pós-Graduação em Educação. Universidade de São Carlos. SP. São Carlos.

Schön, D. A. (1990). Educating the Reflective Practitioner: Toward a New Design for Teaching and Learning in the Professions (Higher Education Series), Jossey-Bass; 1st edition, February. 


\section{Macrothink}

International Journal of Education ISSN 1948-5476 2013, Vol. 5, No. 2

Slavin, R. E. (1983). When does cooperative learning increase student achievement? Psychological Bulletin, 94(3), 429-445. http://dx.doi.org/10.103/0033-2909.94.3.429

Stahl, R. J. (1994). Cooperative learning in social studies: A handbook for teachers. Menlo Park, CA: Addison-Wesley.

Theall, M., \& Franklin, J. (1990). Student Ratings of Instruction: Issues for Improving Practice. New Directions for Teaching and Learning, n. 43. San Francisco: Jossey-Bass.

\section{Copyright Disclaimer}

Copyright reserved by the author(s).

This article is an open-access article distributed under the terms and conditions of the Creative Commons Attribution license (http://creativecommons.org/licenses/by/3.0/). 